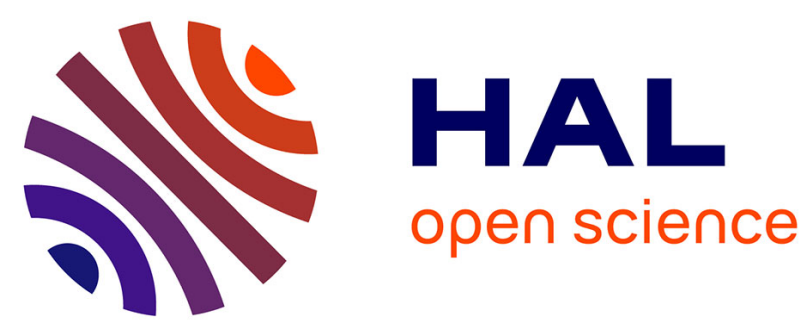

\title{
Tritium in precipitation on 5 sites in North-West France during the 2017-2019 period
}

Olivier Connan, Donovan Maire, Didier Hebert, Luc Solier, Philippe

Laguionie, Marianne Rozet, Marianne Lamotte, Denis Maro

\section{To cite this version:}

Olivier Connan, Donovan Maire, Didier Hebert, Luc Solier, Philippe Laguionie, et al.. Tritium in precipitation on 5 sites in North-West France during the 2017-2019 period. Journal of Environmental Radioactivity, 2020, 212, pp.106129. 10.1016/j.jenvrad.2019.106129 . hal-03045144

\author{
HAL Id: hal-03045144 \\ https://hal.science/hal-03045144
}

Submitted on 21 Dec 2021

HAL is a multi-disciplinary open access archive for the deposit and dissemination of scientific research documents, whether they are published or not. The documents may come from teaching and research institutions in France or abroad, or from public or private research centers.
L'archive ouverte pluridisciplinaire HAL, est destinée au dépôt et à la diffusion de documents scientifiques de niveau recherche, publiés ou non, émanant des établissements d'enseignement et de recherche français ou étrangers, des laboratoires publics ou privés.

\section{(ㅇ)(1) $\$$}

Distributed under a Creative Commons Attribution - NonCommerciall 4.0 International 


\section{Tritium in precipitation on 5 sites in North-West France during the 2017- 22019 period.}

3 (1)Connan O., ${ }^{(2)}$ Maire D., ${ }^{(1)}$ Hébert D., ${ }^{(1)}$ Solier L., ${ }^{(1)}$ Laguionie P., ${ }^{(1)}$ Rozet M., ${ }^{(1)}$ Lamotte 4 M., ${ }^{(1)}$ Maro D

$5 \quad{ }^{(1)}$ Institut de Radioprotection et de Sûreté Nucléaire (IRSN), PSE-ENV/SERIS/LRC, Radioecology Laboratory, , 6 BP10, rue Max Pol Fouchet, 50130 Cherbourg-Octeville, France.

$7 \quad{ }^{(2)}$ Institut de Radioprotection et de Sûreté Nucléaire (IRSN), PSE-ENV/SAME/LMN, Nuclear Metrology

8 Laboratory, BP35, rue de l'écluse, 78119 Le Vésinet, France

$9 *$ Corresponding author:

10 E-mail adress: olivier.connan@irsn.fr

11 IRSN

12 Cherbourg-Octeville Radioecology Laboratory

13 Rue Max Pol Fouchet

$14 \quad$ BP10

1550130 Cherbourg Octeville

$16 \quad \mathrm{Tel}(33) 233014108$

Fax (33) 233014130 


\section{1. Introduction}

3 Tritium $\left({ }^{3} \mathrm{H}\right)$ is a low energy $\beta$-emitting radionuclide with a half-life of 12.32 years. Tritium is produced by naturally-occurring processes through the interaction of gases and cosmic radiation. Natural abundance is estimated at about $4.5 \mathrm{~kg}$ of tritium, produced at an average rate of 0.32 atom. $\mathrm{cm}^{-2} \cdot \mathrm{s}^{-1}$ (Masarik and Beer, 2009; UNSCEAR, 2016), corresponding to $\approx 258$ g.y (Oms et al., 2019). Atmospheric tests of nuclear weapons between 1945 and 1980 led to an estimated release of $668 \mathrm{~kg}$, corresponding to about $24210^{6} \mathrm{TBq}$, during that period (Okada and Momoshima, 1993; UNSCEAR, 2000); in 2016, the tritium remaining from the fallout from atmospheric nuclear weapons testing is estimated to be $22-23.5 \mathrm{~kg}$ (Oms et al., 2019). Most of the ${ }^{3} \mathrm{H}$ released by these nuclear explosions was injected into the stratosphere in its hydrogen gas (HT) and methyl tritium gas $\left(\mathrm{CH}_{3} \mathrm{~T}\right)$ forms. The tritium then crosses the tropopause from stratosphere to troposphere. The flux varies over time, with higher fluxes in spring and early summer (Ehhalt et al., 2002). Today, ${ }^{3} \mathrm{H}$ is mainly released into the environment by nuclear power plants, military nuclear facilities and nuclear reprocessing plants (CNSC, 2009; ASN, 2010). Globally, gaseous releases for all nuclear facilities are currently estimated at 11,700 TBq. $\mathrm{y}^{-1}\left(16,000 \mathrm{TBq} \cdot \mathrm{y}^{-1}\right.$ for liquid releases), with reprocessing plants representing approximately $300 \mathrm{TBq} \cdot \mathrm{y}^{-1}$. Artificial gaseous emissions of tritium globally are estimated at around 33 g. $\mathrm{y}^{-1}$. In France, gaseous ${ }^{3} \mathrm{H}$ releases from nuclear power plants are estimated at between 23 and 50 TBq. $\mathrm{y}^{-1}$, with the Orano La Hague fuel reprocessing plant releasing around $70-80 \mathrm{TBq}$ into the atmosphere $\left(\approx 0.2\right.$ g. $\left.\mathrm{y}^{-1}\right)$ depending on the year. Other French facilities (different industries and research centres) release approximately $400 \mathrm{TBq} \cdot \mathrm{y}^{-1}(\approx 1.1 \mathrm{~g} . \mathrm{y})$, the majority of which is attributed to the Valduc and Marcoule centres (UNSCEAR, 2000: UNSCEAR, 2016; IRSN, 2019). In the troposphere, HT forms are oxidized into HTO before being extracted from the atmosphere through precipitation. Since the early 1960s, tritium activities in precipitation have steadily decreased (Tadros et al., 2014, Eyrolle-Boyer et al., 2014).

Tritium activities in precipitation can be very variable locally due to the direct influence of nuclear facilities, but also to the mixing of air masses between the stratosphere and the troposphere, and to the origin of the air mass (marine or continental) at the time of the precipitation. In the northern hemisphere, when the continental surface heats up in the spring, the height of the tropopause increases, causing a larger than normal tritium influx from the stratosphere to the troposphere. This increases its overall tritium concentration, and eventually leads to an increase in the tritium activity measured in rainwater in spring and summer, a phenomenon known as 'spring leak' (Newell, 1963; Gat et al., 2001). The activities in rainwater (but obviously also in water vapour in the air) also depend on latitude, altitude and distance from the sea. When an air mass is marine in origin, water vapour exchanges above the oceans at the sea/atmosphere interface tend to reduce the activity in the air, so 
precipitations have lower tritium activities when the origin of the air mass is oceanic (Gat et al., 2001; Ehhalt et al., 2002; Crawford et al., 2013; Cauquoin et al., 2015; Tadros et al., 2014; Duliu et al., 2018).

Tritium activities in precipitation are monitored by the Global Network of Isotopes in Precipitation (GNIP) in partnership with the World Meteorological Organization (WMO). The database is available through the IAEA (IAEA/WMO, 2019). As part of the GNIP's activities, monthly precipitation samples were collected at 1000 stations in more than 125 countries in the past (International Atomic Energy Agency, 2019). For France, data for precipitations exist for 47 sites but historical tritium data only exist for a few sites (principally Avignon, Brest, Le Mans, Marseille, Orléans, Strasbourg and Thonon Les Bains). The oldest data date from 1963 and the most recent from 2013. For some sites, historical records are intermittent or cover only a few years. In France, the continental site of Thonon Les Bains $\left(46.3722^{\circ} \mathrm{N}, 6.4708^{\circ} \mathrm{E}\right)$ has the longest and most regular monitoring record with 571 measurements spread evenly over the period 1963 to 2012. In the context of our study, the Brest site $\left(48.3600^{\circ} \mathrm{N},-4.5700^{\circ} \mathrm{W}\right)$, will also be of interest, even though only 78 measurements between 1996 and 2002 are available, because it is right on the coast, like the sites we worked with in this study. Other sites across Europe monitored by the GNIP will also be of use to us in this study for comparison (Madrid, Valentia, Punta Delgada).

This study was launched on the basis of the finding that we had few low-level tritium measurements (below $1 \mathrm{~Bq} . \mathrm{L}^{-1}$ ) for precipitations in France. There are plenty of measurements taken as part of the regulatory monitoring of nuclear facilities by health institutions and the nuclear operators themselves for environmental monitoring purposes, but they are almost always at detection limits of several Bq.L${ }^{1}$ (in particular because of water drinking standards) and are usually taken close to facilities so there is a potential direct influence (for example, there are several thousand rainwater measurements for the RNM site (French National Measurement Network (RNM), 2019) but the detection limit for these is usually between 3 and 5 Bq.L ${ }^{-1}$ ). In previous studies (Crawford et al., 2013), measurements of HTO in water vapour in the air revealed extremely low activities on French background sites (where there was no influence from nuclear activities), which prompted us to ask what the real levels in rainwater in France might be. Furthermore, tritium is particularly heavily monitored in France by environmental protection and anti-nuclear associations, which communicate extensively on the subject, so it is important for institutional bodies to have expertise in this area. We therefore decided to measure tritium at low levels in rainwater, mainly on the site of the Cherbourg En Cotentin-LRC (Radioecology Laboratory), based on samples taken twice a month, accompanied by periodic measurements on several other sites. Particular attention was given in this study to quantifying very low values. The aim was ultimately to provide recent data on tritium levels in rainwater in north-west France, the area of particular interest to us (Connan et al., 2017; Maro et al., 2017); a more extensive study covering the whole of France would obviously have been desirable, but this was not possible to 
do rapidly for reasons of low level measurement capacity, so the decision was made initially to restrict it to our normal area of study. In this study we present the results of measurements taken on these sites, most of which are less than $100 \mathrm{~km}$ from nuclear facilities and are therefore potentially impacted by tritium releases into the atmosphere. The results provide up-to-date data, which can be used for comparison purposes. The study does not aim to continue in the long term or to replace monitoring, such as that done by the GNIP.

\section{Materials and methods}

\subsection{Sampling location and collection}

Rainwater was sampled in north-west France (Figure 1b), in the Normandy region on sites at Cherbourg-LRC $\left(49.634^{\circ} \mathrm{N},-1.645^{\circ} \mathrm{W}\right)$, Cherbourg-Town Center $\left(49.639^{\circ} \mathrm{N}-1.628^{\circ} \mathrm{W}\right)$, Omonville La Petite-PTILH $\left(49.694^{\circ} \mathrm{N},-1.8733^{\circ} \mathrm{W}\right)$, Coutances $\left(49.044^{\circ} \mathrm{N},-1.455^{\circ} \mathrm{W}\right)$, Saint-Lô $\left(49.119^{\circ} \mathrm{N}\right.$, $\left.1.107^{\circ} \mathrm{W}\right)$ and in the Brittany region on the Pontrieux site $\left(48.702^{\circ} \mathrm{N},-3.1644^{\circ} \mathrm{W}\right)$. The CherbourgLRC site is at the Radioecology Laboratory of IRSN (the French Institute for Radiological Protection and Nuclear Safety). The Normandy region has several nuclear facilities (Flamanville NPP, Orano NC La Hague reprocessing plant, Cherbourg submarine naval base, Andra's La Hague disposal facility) which could potentially have an impact as regards tritium on atmospheric water vapour and rainwater. The Pontrieux site in the Brittany region is some distance from the Normandy region and is subject to prevailing west or south-west winds from the Atlantic Ocean, so overall it is outside the influence of nuclear facilities. This will be our reference site.

The samples from the Cherbourg-LRC site (30 samples) were taken using an Eigenbrodt pluviometer (Figure 2a), situated $2.5 \mathrm{~m}$ above the ground. This pluviometer has a rain sensor that causes it to open during precipitation and close in dry periods, preventing exchanges between the rainwater and the atmosphere. The tank is a 5-litre amber glass bottle and the pluviometer's surface area measures 452 $\mathrm{cm}^{2}$. The 30 samples were taken between 29/09/2017 and 28/05/2019 over periods of 12 to 43 days (mean $=20$ days). The samples from the Coutances and Saint-Lô sites (18 samples) and the Cherbourg-Town Centre site (11 samples) were taken between 25/09/2018 and 25/03/2019 using a pluviometer specially constructed for periodic short samples, with a surface collection area of $53 \mathrm{~cm}^{2}$, and a $500 \mathrm{ml}$ glass tank containing a floating ball covering the whole surface to limit exchanges between the water and the atmosphere (Figure 2b). Sampling periods varied from 8 to 43 days, with a mean of 16 days (it should be noted that these samples were taken as part of an education programme promoting scientific discovery and openness to society). The samples from the Pontrieux site (15 samples) were taken periodically over short periods ( 2 to 24 hours) using a pluviometer (funnel and polyethylene bottle) with a surface area of $660 \mathrm{~cm}^{2}$ between 19/10/2017 and 18/03/2019. The samples 
from the Omonville la Petite-PTILH site (Figure 1b) were taken as part of other research work and are presented here for comparison with our other sites. The Omonville la Petite-PTILH site is $2 \mathrm{~km}$ north of the Orano NC La Hague plant and is often affected by tritium releases from the plant. Rainwater samples are taken there at a high frequency every 48 hours (if it rains) using a pluviometer with a large surface area $\left(0.25 \mathrm{~m}^{2}\right)$ and an automatic sampling system (Bûlher BU2000 system) where each rainwater sample is stored and refrigerated in a separate glass receptacle in which the surface is covered by a floating ball to prevent exchanges with the atmosphere (if it does not rain for 48 hours, the corresponding bottle is not filled and remains empty). For this site, we present the results obtained over the period 09/2017 to 04/2019 (196 samples). Finally, we also took 3 opportunistic samples on a continental site in central France, at Lusignan $\left(46.416^{\circ} \mathrm{N}, 0.1188^{\circ} \mathrm{E}\right)$ in July 2018 (Figure 1a).

\subsection{Tritium measurements}

The samples taken at the different sites are kept in darkness in cold storage before being prepared and measured using the low level liquid scintillation counting method. Each sample was filtered to 0.45 $\mu \mathrm{m}$ then mixed with a liquid scintillation cocktail in a low diffusion polyethylene vial (with a teflon coating inside the vial). The liquid scintillation cocktail used is Ultima Gold LLT (Perkin Elmer). The water/liquid scintillation cocktail ratio is $70 / 70 \mathrm{ml}$ or $10 / 10 \mathrm{ml}$ depending on the liquid scintillation counter (LSC) used.

The device with the best performance is an ALOKA LSC-LB07 (Hitachi), in which each sample is counted for $24 \mathrm{~h}$. The background count rate and counting efficiency were $2.77 \pm 0.11 \mathrm{cpm}$ and $20.7 \pm 2.4$ $\%$ respectively. The whole batch of samples is counted over 6 cycles ( 6 times the whole batch) of 4 hours for each sample. One batch contains 7 samples maximum in order to ensure the samples remain in the counter for less than one week. Each batch of samples contains one reference sample with a known ${ }^{3} \mathrm{H}$ activity in order to check measurement quality. The LB07 counter is calibrated using groundwater (low level of tritium) spiked with a known quantity of a ${ }^{3} \mathrm{H}$ standard solution. Several standards were made and quenched with nitromethane in order to cover the whole quenching index range of the samples. The decision threshold (SD) was $0.15 \mathrm{~Bq} \cdot \mathrm{L}^{-1}$. Measurement uncertainty (average) was $23 \%, 18 \%$ for samples $>0.5 \mathrm{~Bq} \cdot \mathrm{L}^{-1}$ (depending on the activity) and $50 \%$ for samples < $0.5 \mathrm{~Bq} \cdot \mathrm{L}^{-1}$. Below the SD, the uncertainty was $100 \%$. For the samples counted with the LB07, the results below $\mathrm{SD}=0.15 \mathrm{~Bq} . \mathrm{L}^{-1}$ were indicated in the tables. These 'uncensored' values were used in the mean calculations (Vivier et al., 2012; Puydarrieux et al., 2015). For other samples, we used a TRICARB 3180 TRSL (PerkinElmer) with a counting time of 16 hours per sample. With this 3180 TRSL LSC, the decision threshold (SD) is $1.0 \mathrm{~Bq} . \mathrm{L}^{-1}$ in the sample. The background count rate and counting efficiency were $2.09 \mathrm{cpm}$ and $14.9 \%$. The measurement uncertainty depends on the level of activity, but based on 151 significant measures (>1 Bq. $\left.\mathrm{L}^{-1}\right)$ on the PTILH site, average uncertainties is $31 \%$. 
Our measurement practices are regularly validated by means of comparison exercises between French and international laboratories. Our measurement laboratories are also currently involved in writing a standard on tritium measurement (XP NF M60-824, test method for analysis of tritium in free water and organically bound tritium in environmental matrices). During this study, 67 samples were measured with the better-performing ALOKA LSC-LB07 (Hitachi) and 10 samples were measured with the TRI-CARB 3180 TRSL (PerkinElmer) for the Pontrieux, Cherbourg-LRC, Cherbourg-Town Centre, Coutances, Saint-Lô and Lusignan sites. For the Omonville-PTILH site, the 196 samples were measured by the TRI-CARB 3180 TRSL (PerkinElmer).

\section{Results}

\section{1: Cherbourg-LRC site}

The results for the Cherbourg-en-Cotentin-LRC site are presented in Figure 3 and Table A1. The values range from 0.2 to $2.42 \mathrm{~Bq} \cdot \mathrm{L}^{-1}$. The mean value is $1.00 \mathrm{~Bq} \cdot \mathrm{L}^{-1}$. In Figure 3, it can be seen that the minimum values are measured in the October to March periods, corresponding to winter. The maximum values are measured between May and July 2018, then in May 2019 (an upwards trend in activities is observed from April 2019), which accords with the 'spring leak' phenomenon (the increase is around 0.7 Bq. $\left.\mathrm{L}^{-1}\right)$. Two values seem to stand out in the graph: the highest value (2.42 $\pm 0.22 \mathrm{~Bq} . \mathrm{L}^{-}$

${ }^{1}$ ) was observed between 15/10/2018 and 05/11/2018 and a value of $1.35 \pm 0.20 \mathrm{~Bq} \cdot \mathrm{L}^{-1}$ was observed between 03/02 and 01/03/2019. The value $2.42 \mathrm{~Bq} \cdot \mathrm{L}^{-1}$ is confirmed by the measurement over a similar period (23/10 to 06/11/2018) of an activity of $3.02 \pm 0.23$ Bq.L $\mathrm{L}^{-1}$ on the Cherbourg-Town Centre site $1.3 \mathrm{~km}$ away (Figure 3 and Table 2). Examination of the pluviometer data and wind directions indicates that, during 2 rain events (26/10 and 01/11/2018) during this period, the wind was coming from the direction of the Orano NC plant $18 \mathrm{~km}$ to the north-west, with a pluviometry volume over these two episodes representing $10 \%$ to $15 \%$ of the total over the whole period. In the case of the 1.35 Bq. $L^{-1}$ value measured between 03/02 and 01/03/2019, the higher value can be explained by a rainfall episode on 01/03/2019, between 0:00 hrs and 08:00 hrs, with $10 \mathrm{~mm}$ of rain (i.e. $15 \%$ of the total collected during the period), which also originated in an air mass from the north-west, the direction of the Orano plant (this is confirmed by significant ${ }^{85} \mathrm{Kr}$ activity, a marker of atmospheric releases from the Orano plant, Connan et al., 2017). In these conditions, where rainfall is concomitant with an air mass affected by anthropogenic atmospheric releases (of HTO, HT and ${ }^{85} \mathrm{Kr}$ ), it is entirely possible for the value to double or triple over a sampling period of 15 to 30 days, just with a single rainfall episode (specific experiments conducted by our team in 2016-2017 to collect rain from the plume emitted by the Orano plant at a distance of only 1 to $3 \mathrm{~km}$ from the plant, showed values ranging from 09 to 54 Bq. $\mathrm{L}^{-1}$; so if for example $10 \%$ of the volume collected has an activity of 9 Bq.L $\mathrm{L}^{-1}$, for $100 \mathrm{~mm}$ of 
rainwater, the activity can be multiplied by 3 compared to the mean activity). Overall, for the Cherbourg-LRC site, rainwater values below $1 \mathrm{~Bq} . \mathrm{L}^{-1}$ are the norm, but it only take one episode of rain has to be associated with winds from the Orano NC plant at La Hague for activities to increase significantly.

\section{2: Pontrieux site (reference)}

The results for the Pontrieux site are presented in Figure 3 and Table 1. This site is some distance away from any nuclear facilities, in an area where the prevailing winds are from the south-west; it is a site influenced by the sea, with the Channel approximately $10 \mathrm{~km}$ to the north and the Atlantic Ocean $100 \mathrm{~km}$ to the west (Figure 1). The values range from 0.01 to $1.19 \mathrm{~Bq} \cdot \mathrm{L}^{-1}$. Only one value (1.19 Bq.L${ }^{1}$ ) exceeds $1 \mathrm{~Bq} \cdot \mathrm{L}^{-1}$ and in nearly half of cases the values are below the $\mathrm{SD}$ (7 values $<0.15 \mathrm{~Bq} . \mathrm{L}^{-1}$ out of 15 samples). The activities measured on this site are clearly the lowest in our study. For each sample, we traced the back trajectories (NOAA/HYSPLIT model; https://ready.arl.noaa.gov/HYSPLIT_agreement.php) arriving at this site to have an idea of the origin of the air masses when each sample was taken (Figure A1), and we have indicated the direction of origin deduced from this in Table 1; we show that, when the wind comes from the south or east with a continental component (land), the values for HTO in rainwater are at their highest. When the wind for the last hours before sampling comes from the north/north-west with an influence of the Channel, which is more affected by tritium than the Atlantic (Oms et al., 2019), values are also significant. On the other hand, when the air masses come from the south-west or the west, from the Atlantic Ocean, the values are always the lowest, below the decision threshold of $0.15 \mathrm{~Bq} \cdot \mathrm{L}^{-1}$. The values are shown in Figure 3 to compare with the values measured on the two sites of Cherbourg. The highest activities are measured during the same period (May to July 2018) as on the Cherbourg-LRC site (Figure 3) which, combined with the continental component of the air masses at these times, contributes to this significant increase (a general increase can be seen from values of 0.15 to values of 0.4 to $1 \mathrm{~Bq} \cdot \mathrm{L}^{-1}$ ). It is worth noting that on this site the activities in rainwater are very low, and that values of around 0.15 Bq. $L^{-1}$ and below are probably the level background for French sites mainly under the influence of air masses from the sea and not affected by nuclear industries. The mean calculated on the basis of all the activity values (including uncensored values $<\mathrm{SD}$ ) is $0.36 \mathrm{~Bq} \cdot \mathrm{L}^{-1}$.

\section{3: Coutances, Saint-Lô and Cherbourg-Town Centre sites}

The results for the 3 sites at Coutances, Saint-Lô and Cherbourg-Town Center are presented in Table 2. In view of the prevailing winds, the Cherbourg-Town Centre site is the most susceptible to the impact of the region's nuclear facilities. The Coutances and Saint-Lô sites are respectively 76 and $83 \mathrm{~km}$ south of these facilities (Figure 1b), and the prevailing wind direction on these sampling sites is not from these facilities. In the case of Coutances and Saint-Lô, the maximum values are obtained during the same period: $1.56 \pm 0.19$ Bq. $\mathrm{L}^{-1}$ from $18 / 10 / 2018$ to $08 / 11 / 2018$ and $2.15 \pm 0.20 \mathrm{~Bq} \cdot \mathrm{L}^{-1}$ 
from 19/10/2018 to 06/11/2018 respectively. The other values indicate low activity levels $<0.4$ Bq. $\mathrm{L}^{-1}$. The mean values for Coutances and Saint-Lô are 0.55 and 0.64 Bq. $\mathrm{L}^{-1}$ respectively (Figure 5). In this geographical area to the south of the region, the activities tend to be low overall, though higher than those at the reference site at Pontrieux. These slightly higher activities are probably explained by the tritium levels in the seawater of the Channel, a few tens of kilometres to the west. Finally, the activities at the Cherbourg-Town Centre site range from 0.38 to $3.02 \mathrm{~Bq} \cdot \mathrm{L}^{-1}$ with a mean activity of 1.19 Bq. $\mathrm{L}^{-1}$. This mean is higher than at the other two sites and agrees well with those for CherbourgLRC, which is $2 \mathrm{~km}$ away (Figure 1).

\section{4: Omonville La Petite-PTILH site}

The measurements in rainwater at the Omonville La Petite (PTILH) site every 48 hours between 25/09/2017 and 30/04/2019 (196 measurements) are presented in Figure 4. The PTILH site is used extensively by IRSN for monitoring and research, which explains why data are available for very short time intervals of 48 hours. This site is $2 \mathrm{~km}$ north of the Orano NC La Hague plant (Figure 1) and is regularly affected by gaseous tritium releases from the plant (87\% in the form of HT, but with median HTO activities in water vapour in the air of $66 \mathrm{~Bq} . \mathrm{L}^{-1}$ in the plume, Connan et al., 2017), which can have an impact on the activity in rainwater in the precipitation event takes place on an air mass coming from the plant. The HTO activities in rainwater on this site range from $<1 \mathrm{~Bq} \cdot \mathrm{L}^{-1}$ to $25.5 \mathrm{~Bq} \cdot \mathrm{L}^{-1}$ maximum (Figure 4). The mean value is $3.8 \mathrm{~Bq} \cdot \mathrm{L}^{-1}$ (mean calculated by using $1 \mathrm{~Bq} . \mathrm{L}^{-1}$ when the value is $<1 \mathrm{~Bq} \cdot \mathrm{L}^{-1}$ ) but would be lower if we have better precision $<1 \mathrm{~Bq} \cdot \mathrm{L}^{-1}$. This value reflects the noncontinuous but recurrent influence of the Orano NC plant compared with data measured at the other sites presented above. It is worth noting that, despite the plant's proximity, many measurements are nevertheless below 1 Bq.L.-1, especially between October 2017 and February 2018. During this period (from 08/10/2017 to 21/01/2018 to be precise), the two main stacks emitting tritium at the Orano NC plant were shut down for maintenance. The measurements at this site are therefore representative of activities to be found on a site heavily impacted by atmospheric tritium releases, with high significant variability due to its short distance from the industrial site. Finally, to provide further information about the activities in rainwater under the direct influence of the Orano plant, specific experimental work was conducted by our team in 2016-2017 to collect rainwater under the plume emitted by the Orano plant. The rainwater samples were taken, checking by means of real-time measurements of ${ }^{85} \mathrm{Kr}$ that the rainwater episode was in an area under the influence of the gaseous release (rainwater was sampled in a tank with a large surface area installed on a trailer instrumented to measure ${ }^{85} \mathrm{Kr}$, that could be moved to the location of the release while in the rain): the values obtained from 6 samples at separate times range from 9 to $54 \mathrm{~Bq} \cdot \mathrm{L}^{-1}$. 


\section{Discussion}

244 Figure 5 summarises the results obtained at our different measurement sites. Unsurprisingly, the graph shows levels that increase from our reference site at Pontrieux, where measurements were very similar to those at Saint-Lô and Coutances, to the Cherbourg-LRC and Cherbourg-Town Centre sites, where the tritium levels were higher. Finally, the Omonville-PTILH site is distinctive in character due to its situation $2 \mathrm{~km}$ from the Orano reprocessing plant at La Hague, with higher activity levels and wider variations. We sought to verify the precipitation amount effect (Tadros et al., 2014), which is reflected in an inverse correlation between the tritium activity in rainwater and the amount of rain. Tritium in the form of HTO in water vapour in the air condenses in rain, concentrating the tritium in light rain and diluting it in more important rain. This effect is more significant on continental sites and also depends on the timing between stratosphere-troposphere exchanges and the annual rain cycle on a site (Tadros et al., 2014). If the spring-summer tritium peak related to stratosphere-atmosphere exchanges coincides with light rainfall, the effect will be maximised. To determine whether this amount effect is observed on the Cherbourg-LRC site, we normalised each tritium activity to the total average and correlated this with the precipitation (Figure 6a). Although this is a coastal site, the precipitation amount effect is observed, with a very clear negative correlation. The same plot was done for the Omonville-PTILH site (Figure 6b); in this case the effect is not visible because the tritium activities are affected too much by the atmospheric tritium emissions from the Orano reprocessing plant.

Our measurements have the particular characteristic of having been done (except in the case of the Pontrieux site) in a region significantly influenced by the sea (the Cherbourg peninsula is surrounded by water, Figure 1b) with prevailing winds coming from the sea (south-west or north-east for $75 \%$ of the time), but also potentially impacted by atmospheric tritium releases from nearby nuclear facilities. It should also be mentioned that the Orano plant also releases tritium into the sea in liquid waste discharges (12 to 14 PPq. ${ }^{-1}$ ) leading to activities in the seawater that range from 2 to $20 \mathrm{~Bq} \cdot \mathrm{L}^{-1}$. Based on our seawater monitoring over the last 3 years, the mean activity in seawater at the north-west tip, near the release stack, is $12 \mathrm{~Bq} . \mathrm{L}^{-1}$. It is $6 \mathrm{~Bq} \cdot \mathrm{L}^{-1}$ in the eastern part of the region, and the activities are lower, at between 1 and $3 \mathrm{~Bq} \cdot \mathrm{L}^{-1}$ in the southern part of the Channel (Gulf Normand-Breton), i.e. to the west of the Coutances and Saint-Lô sites. Figure 5 could reflect that, i.e. that the PTILH site is directly influenced by atmospheric releases from the Orano plant, and the Cherbourg-LRC and Town

272 Centre sites are also influenced but to a lesser degree, whereas the Coutances and Saint-Lô sites,

273 which are not under the prevailing winds of the plant, are influenced by marine air masses from the

274 west, which pass over waters with slightly higher tritium levels than normal. Finally, the Pontrieux

275 site, under the influence of air masses from the Atlantic most of the time, with a few exceptions presents very low activities. 
It is therefore worth comparing our results with existing GNIP data for France and Europe. In Figures 7 and 8 we have reproduced the GNIP data from several stations chosen by us (Figure 1a): the Thonon Les Bains site $\left(46.37^{\circ} \mathrm{N},-6.47^{\circ} \mathrm{E}\right)$ because this is the best documented site in France (continental site) and the one most often used as a reference, the Brest site at the western tip $\left(48.36^{\circ} \mathrm{N},-4.57^{\circ} \mathrm{W}\right.$, data from 1996 to 2002 only), the Valentia site $\left(51.93^{\circ} \mathrm{N}-10.25^{\circ} \mathrm{W}\right)$ at the south-western tip of Ireland, and the Punta Delgada site $\left(37.77^{\circ} \mathrm{N},-25.65^{\circ} \mathrm{W}\right)$ in the middle of the Atlantic (Azores), because these sites are a long way from any nuclear facilities but are strongly influenced by the Channel and the Atlantic, and in this respect they are similar to our measurement sites. Finally, the Madrid site $\left(40.41^{\circ} \mathrm{N}\right.$, $3.67^{\circ} \mathrm{W}$ ) in the centre of Spain, which is a continental site but in a region with few nuclear facilities and winds that, on a larger scale, come mainly from the Atlantic, seemed to be worth looking at.

First, we compared the data for 1996-2016 from the Thonon Les Bains, Madrid, Brest, Valentia and Punta Delgada sites (Figure 7). Over the whole period, much lower values are observed (difference of approximately 0.5 to $0.7 \mathrm{~Bq} \cdot \mathrm{L}^{-1}$ ) at the marine sites of Brest, Valentia and Punta Delgada than at the Madrid and Thonon Les Bains sites, both of which always have higher values. This reflects the respective marine and continental influences of these two groups of stations (with comparable latitudes for Valentia, Brest and Thonon Les Bains in particular). A difference between the values for Thonon Les Bains and Madrid is also always observed, with Madrid having lower activities than Thonon Les Bains (by around 0.2 to 0.5 Bq.L ${ }^{-1}$ ). Figure 8 shows the data for Thonon Les Bains, Brest and Valentia, focusing on the period 1995-2005 when data was simultaneously acquired for all 3 sites. There is a high level of agreement between the Brest and Valentia data (despite the fact that they are $600 \mathrm{~km}$ apart, separated by the Atlantic Ocean, the Channel and the Irish Sea), and there is always a difference of around 0.5 Bq.L-1 compared to the Thonon Les Bains data. Because the GNIP data stop in 2002 (Brest), 2012 (Thonon Les Bains, Punta Delgada, Valentia), and 2015 (Madrid), we used a model inspired by Jean-Baptiste et al. (2019), based on a sine function fitted to the most recent data from Thonon Les Bains and Valentia to simulate the data for each site up to 2019 so that we could compare it with our measurements. This model is the sum of two components, the first corresponding to the exponentially decreasing mean value of tritium in rainwater over time, and the second describing seasonal variability, with an amplitude that diminishes over time (see Jean-Baptiste et al. (2019), for more details).

Figure 9 presents the data simulated on the basis of the models for the Thonon Les Bains and Valentia sites, together with our measurements taken in 2018-2019 on the Cherbourg-LRC and Pontrieux sites. The Valentia measurements are shown on the graph up to 2012, to observe the agreement between the model and the measurements. It can be seen that the measurements from our reference site at Pontrieux appear to be similar (or even lower than) to the measurements at the Valentia site in the case of the lowest activities. However, the few highest activities on the Pontrieux site $\left(\approx 1 \mathrm{~Bq} \cdot \mathrm{L}^{-1}\right.$ on 3 occasions) are higher than those given by the model as a maximum. This reflects the continental 
influence in certain periods, as explained in section 3.2; this influence should not exist in Valentia.

314 The measurements taken at Cherbourg-LRC are rather similar to the simulated measurements for the 315 Thonon Les Bains site than that of Valentia, but the amplitude is greater, and higher values (> 1 Bq.L-

$312^{1}$ ) on several occasions bear witness to the sporadic impact of the nearby nuclear facilities (though in $31780 \%$ of cases the Cherbourg-LRC measurements are consistent with the model's predictions for 318 Thonon Les Bains). Furthermore, over the period from 02 to 04/07/2018, we took 3 individual samples 319 of rainwater from a site in central France (Lusignan, $46.416^{\circ} \mathrm{N}, 0.1188^{\circ} \mathrm{E}$, Figure 1a) with a mean 320 result of $1.11 \pm 0.16$ Bq.L ${ }^{-1}$ (Figure 9, green dots); these 3 measurements coincide well with the model 321 for Thonon les bains.

322 The different comparisons show that the Thonon Les Bains site may be affected by diffuse tritium 323 releases from nuclear facilities because, when we see the measurements (Figures 7 and 8) the site always has slightly higher activities than coastal sites and especially larger variations. The prevailing winds come mainly from the south-west and north-east at this site, and there are a number of nuclear sites less than $200 \mathrm{~km}$ away to the south-west (several NPPs, the CEA site at Marcoule); moreover, even when the prevailing winds are not blowing, the CEA's nuclear site at Valduc, which is the largest emitter of gaseous tritium in France, is only $140 \mathrm{~km}$ to the north-west and can probably sporadically affects the tritium content of the air and rainwater in this region. In view of our measurements at Pontrieux and the simulations for the Valentia site, a site on the Atlantic coast in western France would certainly show lower tritium levels in rainwater than at Thonon Les Bains and would be of interest. The Cherbourg site, although under the potential influence of many nuclear sites, nevertheless does not, with rare exceptions, give very high measurements for tritium content in rainwater, and the measurements appear comparable with the simulations for Thonon Les Bains, which would not have seemed obvious before this work.

Several recent studies in different countries throughout the world have recorded tritium activities in rainwater in the last few years. For European sites in Germany, Romania and Ukraine (Berlin, Stuttgart, Regensburg, Vienna, Krakow, Rm.Valcea), Duliu et al. (2018) give mean annual values of 1.1 to $1.4 \mathrm{~Bq} . \mathrm{L}^{-1}$, with a maximum between May and August corresponding to the presence of the spring leak mechanism. They also indicate a decrease of around $1.4 \%$ per year in background levels in rainwater since 2000. For a site in Hanoi (at a latitude of $21^{\circ} \mathrm{N}$ ) in the period 2011-2016, based on monthly measurements, Anh et al. (2018) give values ranging from 0.06 to $0.83 \mathrm{~Bq} . \mathrm{L}^{-1}$, with a mean of $0.30 \pm 0.15 \mathrm{~Bq} \cdot \mathrm{L}^{-1}$, showing that the site is influenced by the tropical climate and particularly by the effect of moisture from the sea. Tadros et al. (2014) did a comprehensive study of tritium in rainwater in Australia during the period 1963-2011. They give lower tritium values in rainwater on coastal sites, with less marked seasonal variations than on inland sites. For the period 2005-2011, the authors give a range of values from 0.10 (northern Australia) to $0.38 \mathrm{~Bq} . \mathrm{L}^{-1}$ (southern Australia, Melbourne). Harms et al. (2016) give measurements in California (USA) for 18 sites, including coastal sites near the 
Pacific Ocean and more continental sites. The mean value for the coastal sites is $0.23 \pm 0.04 \mathrm{~Bq} . \mathrm{L}^{-1}$, while for the other sites the values range from 0.5 to $0.66 \mathrm{~Bq} . \mathrm{L}^{-1}$. Our results are consistent with these various studies. Finally, it could be note in the literature the very particular data of Chae and Kim (2018), who took measurements in rainwater around the Wolsong nuclear power plant site in Korea, which has four pressurized heavy water reactors and two pressurized water reactors. The activities in rainwater vary from 0.3 to $1090 \mathrm{~Bq} \cdot \mathrm{L}^{-1}$ and the least affected site presents activities of 0.8 to $10 \mathrm{~Bq} \cdot \mathrm{L}^{-1}$ with a mean of $2.3 \mathrm{~Bq} . \mathrm{L}^{-1}$. It is worth noting the difference in magnitude of the values linked to the presence of pressurized heavy water reactors. Finally, mention should be made of recent work done at Corte $\left(42.300570^{\circ} \mathrm{N}, 9.148592^{\circ} \mathrm{E}\right)$ on the island of Corsica (France) in the Mediterranean Sea, between 18/04/2017 and 04/04/2018 on 46 rainfall episodes. Juhlke et al. (2019) give a range of activities from 0.19 to $1.19 \mathrm{~Bq} \cdot \mathrm{L}^{-1}$, with a mean of $0.53 \mathrm{~Bq} \cdot \mathrm{L}^{-1}$, which are very similar values to those measured on our sites at Coutances and Saint-Lô in particular.

\section{Conclusion}

We measured tritium activity in rainwater at 5 sites in north-west France between October 2017 and May 2019. The aim was to provide recent data for a reference site (Pontrieux) most of the time influenced by marine air masses from the Atlantic Ocean, and for several sites in the Manche department in north-west France, where several major nuclear facilities are located. The activities measured were compared with IAEA-GNIP data, using measured data and simulations from a model to complete the data sets up to 2019. On our reference site (Pontrieux), the activities were often below the decision threshold $\left(<0.15\right.$ Bq. $\left.\mathrm{L}^{-1}\right)$ and are comparable with the activities expected at GNIP stations with a marine influence (Valentia, Ireland; Punta Delgada, Azores). The measurements taken in the south of the Manche department (Coutances, Saint-Lô) also show that, for most of the time, the nuclear facilities (approximately $80 \mathrm{~km}$ further north) have no impact. For the Cherbourg-LRC and Cherbourg-Town Center sites, which are closer to the Orano NC La Hague reprocessing plant (approximately $20 \mathrm{~km}$ East South east away), the activities are low overall (mean values of 1.00 and $1.19 \mathrm{~Bq} . \mathrm{L}^{-1}$ respectively) but these values probably bear witness both to the direct influence of air masses with a slightly higher tritium content (explained by rain pushed by winds from the Orano plant), and probably a continuous emission/exchange phenomenon at the interfaces with the surrounding sea, in which the tritium activity is higher than elsewhere. Despite this, the data from the Cherbourg-LRC site are with few exceptions comparable with data who can be predicted for the GNIP reference site in France at Thonon Les Bains. We also showed that a single episode of rain on a marked tritium air mass, even if it represents only $10 \%$ of the total volume of water from the sample for example, could significantly increase tritium activity. The precipitation amount effect could be shown on the Cherbourg LRC site, which is not the case on the Omonville-PTILH site, which is too 
influenced by the Orano plant, with important variation of activities between $<1$ and $25 \mathrm{~Bq} \cdot \mathrm{L}^{-1}$, and a average activity of 3.8 Bq. $\mathrm{L}^{-1}$ for 48 -hour period rain event.

This work also show that IAEA-GNIP data from the European stations nearest to France with a marine influence (those we worked with were Valentia and Punta Delgada) would be more relevant that the French IAEA site of Thonon Les Bains (with a sine function model for example) to correctly estimate tritium activities in rainwater for regions of France on the Atlantic coast. These activities are mostly less than $0.2 \mathrm{~Bq} . \mathrm{L}^{-1}$. This work, which compares periodic measurements on a few sites with sets of measurements taken over a long period of time, shows the interest of the IAEA-GNIP long-term data sets but also the need for more recent data than the existing data, the latest of which dates from 2012. Finally, our work shows that a reference station monitored regularly over the long term on France's west coast, bordering the Atlantic Ocean, would be very useful because a one-off study like ours is not enough to provide data for use in climate models.

\section{Acknowledgements}

We would like to thank pupils at the Thomas Helye high school in Cherbourg, the Institut Agneaux in Saint-Lô, and the agricultural high school in Coutances for their help with some of the sampling, and P. Connan for the sampling at the Pontrieux site.

\section{References}

Anh H.L., Anh V.T., Giap T.V., Thinh N.T.H., Minh T.K., Hoai V., 2018. Monitoring of tritium concentration in Hanoi's precipitation from 2011 to 2016. Journal of Environmental Radioactivity, 192, 143-149.

ASN, 2010. Livre blanc du tritium (http://livre-blanc-tritium.asn.fr/fichiers/Tritium_CHAP_5-5.pdf. $278 \mathrm{p}$.

Cauquoin A., Jean-Baptiste P., Risi C., Fourré E., Stenni B., Landais A., 2015. The global distribution of natural tritium in precipitation simulated with an Atmospheric General Circulation Model and comparison with observations. Eart and Planetary Science letters, 427, 160-170.

Chae J.S., Kim G., 2018. Dispsersion and removal characteristics of tritium originated from nuclear power plants in the atmosphere. Journal of Environmental Radioactivity, 192, 524-531.

CNSC, 2009. Rejet de tritium et conséquences sur les doses au Canada en 2006. INFO-0793. 48pp.

Connan O, Hebert D., Solier L., Maro D., Pellerin G., Voiseux C., Lamotte M., Laguionie P., 2017.. Atmospheric tritium concentrations under influence of AREVA NC La Hague reprocessing plant (France) and background levels. Journal of Environmental Radioactivity, 177, 184-193.

Crawford J., Hugues C.E., Parkes S.D., 2013. Is the isotopic composition of event based precipitation driven by moisture source or synoptic scale weather in the Sydney Basin, Australia ?. Journal of Hydrology, 507, 213-226. 
Duliu O.G, Varlam C., Shnawaw M.D., 2018. 18 years of continuous observation of tritium and atmospheric precipitations in Ramnicu Valcea (Romania) : a time series analysis. Journal of Environmental Radioactivity, 190, 105-110.

Ehhalt D.H., Rohrer F., Schauffer S., Pollock W., 2002. Tritiated water vapor in the stratosphere; vertical profiles and residence time., J. Geophysical Reserch, 107, 4757-1762.

Eyrolle-Boyer F., Boyer P., Claval D., Charmasson S., Cossonet C., 2014. Apparent enrichment of organically bound tritium in rivers explained by the heritage of our past. Journal of Environmental Radioactivity, 136, 162-168.

Gat J., Mook W., Meijer H., 2001. Tritium in atmosphere. Environmental isotopes in the hydrological cycle, principles and applications, vol II, IAEA, Vienna.

Harms P.A., Visser A., Moran J.E., Esser B.K., 2016. Distribution of tritium in precipitation and surface water in California. Journal of Hydrology, 534, 63-72.

IAEA/WMO, 2019. Global network of isotopes in precipitation. The GNIP Database. Accessible at: http://www-naweb.iaea.org/napc/ih/IHS_resources_gnip.html.

IRSN, 2019. Bilan de l'état radiologique de l'environnement français de 2015 à 2017. 354 pp

Jean-Baptiste P., Genty D., Fouré E., Régnier E., 2019. Tritium dating of dripwater from Villars Cave (SW-France). Applied Geochemistry, 107, 152-158.

Juhlke T.R, Sultenfub J., Huneau F., Garel E., Santoni S., Barth J.A.C., Van Geldern R., 2019. Tritium as hydrological tracer in Mediterranean precipitation events. Atmospheric Chemistry and Physics, in review.

Maro D., Vermorel F., Rozet M., Aulagnier C., Hebert D., Le Dizes S., Voiseux C., Solier L., Cossonnet C., Godinot C., Fievet B., Laguionie P., Connan O., Cazimajou O., Morillon M., Lamotte M., 2017. The VATO project: development and validation of a dynamic transfer model of tritium in grassland ecosystem: Journal of Environmental Radioactivity, 167, 235-248.

Masarik J., Beer J., 2009. An updated simulation of particle fluxes and cosmogenic nuclide production in the earth's atmosphere. J. Geophyscial research, 114, D11103.

Newell R.E.,1963. Transfer through the tropopause and within the stratosphere. Q.J.R. Meteorol. Soc., 89 (380), 167-204.

Okada S., Momoshima N., 1993. Overview of tritium, characteristics, sources, and problems. Health Phys., 65, 595-609.

Oms P.E., Bailly Du Bois P., Dumas F., Lazure P., Morillon M., Voiseux C., Le Corre C., Cossonet the Total Environment, 656, 1289-1303.

Puydarrieux, S., Bruel, V., Rivier, C., Crozet, M., Vivier, A., Manificat, G., Thaurel B., Mokili M., Philippot B., Bohaud, E., 2015. Measurement sum theory and application-Application to low level measurements. https://inis.iaea.org/search/search.aspx?orig_q=RN:47056819)

RNM, French réseau National de Mesures 2019. https://www.mesure-radioactivite.fr/.

Tadros C.V., Hughes C.E., Crawford J., Hollins S.E., Chisari R., 2014. Tritium in Australian precipitation: a 50 year record. Journal of Hydrology, 534, 63-72. 
461 UNSCEAR, 2016. Sources, effects and risks of Ionizing Radiation. In Annex C, biological effects of 462 selected internal emitters, tritium, United Nations Scientific Committee on the effects of Atomic 463 Radiation. UNSCEAR, 122 pp.

464 Vivier, A., Manificat, G., Picolo, J. L., Fleury, S., Mokili, M., Guo, X., 2012. Decision threshold associated with multiple measurements. Application to the synthesis of the environment monitoring results. Radioprotection, 47(1), 51-77. 


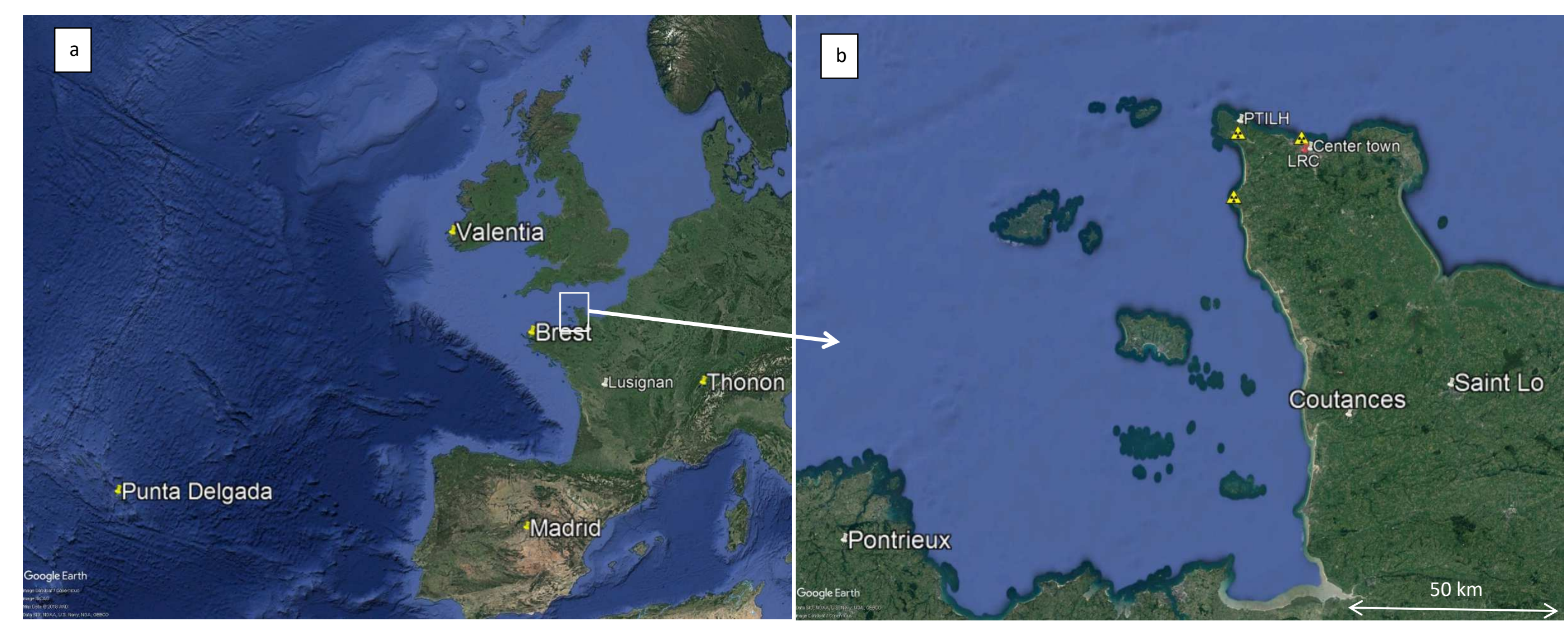

Figure 1 : (a) Location of the global network of isotopes precipitation (GNIP) stations (IAEA/WMO 2019) used in this work (yellow dots) and (b) location of local sampling site of our study (white and red dots). Positions of nuclear facilities were reported on (b). 
Figure 2 : (a) Pluviometer Eigenbrodt used at Cherbourg-LRC site, (b) Pluviometer used on others sites.

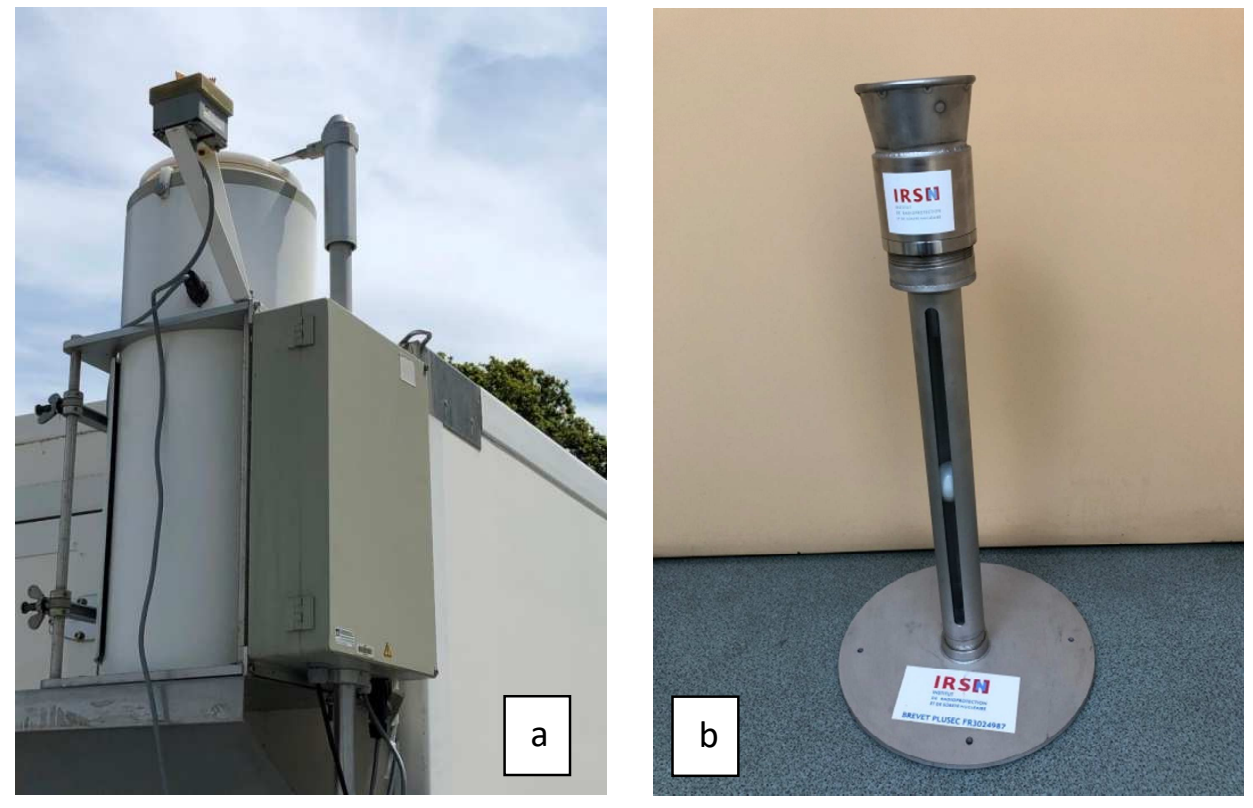


Figure 3: Evolution of tritium activities in rainwater $\left(\mathrm{Bq} . \mathrm{L}^{-1}\right)$ at Cherbourg-LRC site (biMonthly measurements), at Pontrieux and Cherbourg Center Town sites (intermittent measurements). The dotted line represent the decision thresholds for our measurements (below its 'uncensored' values).

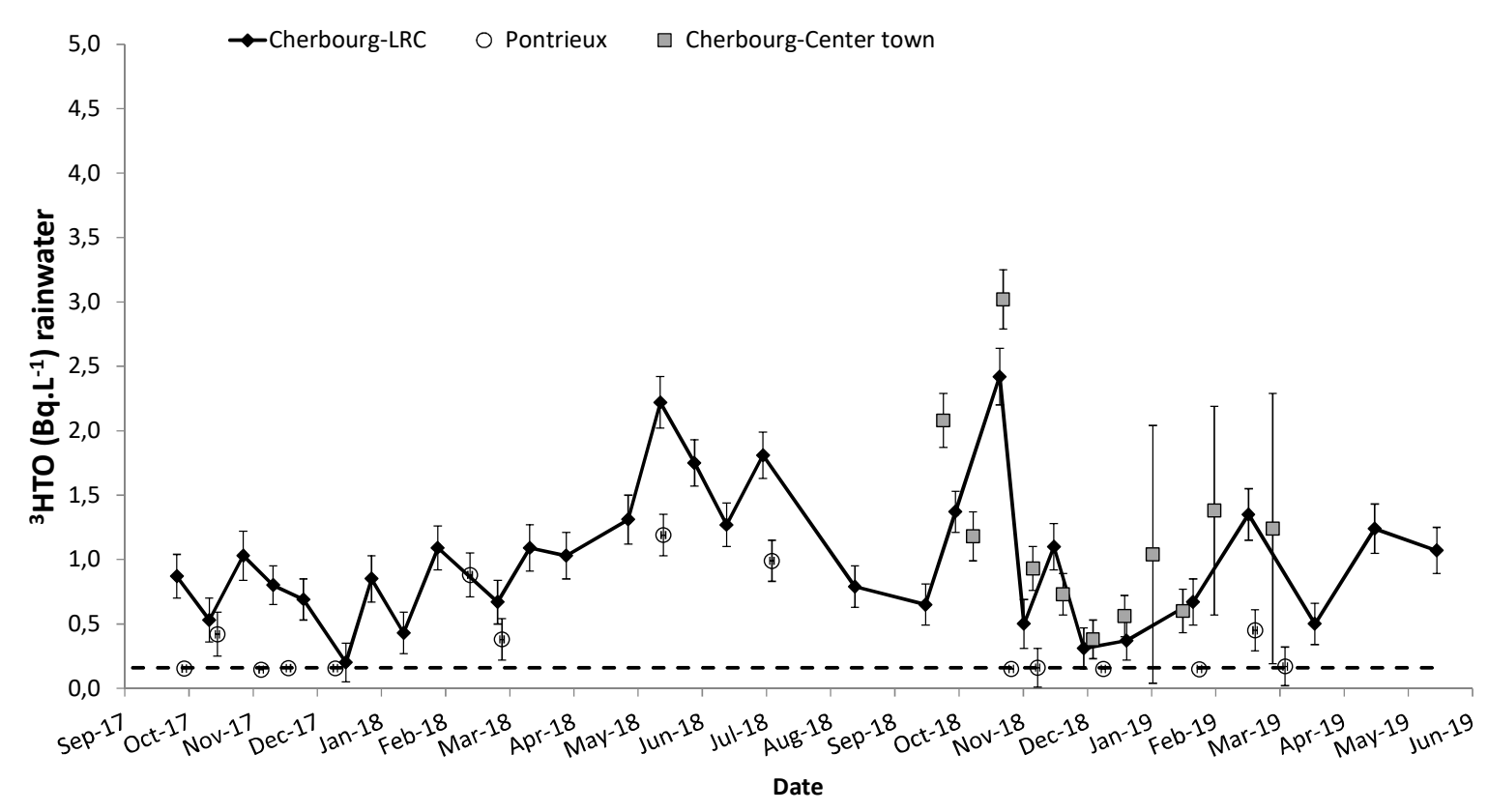

Figure 4 : Evolution of tritium activities in rainwater (Bq.L $\left.{ }^{-1}\right)$ at Omonville La Petite PTILH site (the black bar represent activities $<1 \mathrm{~Bq} \cdot \mathrm{L}^{-1}$ ).

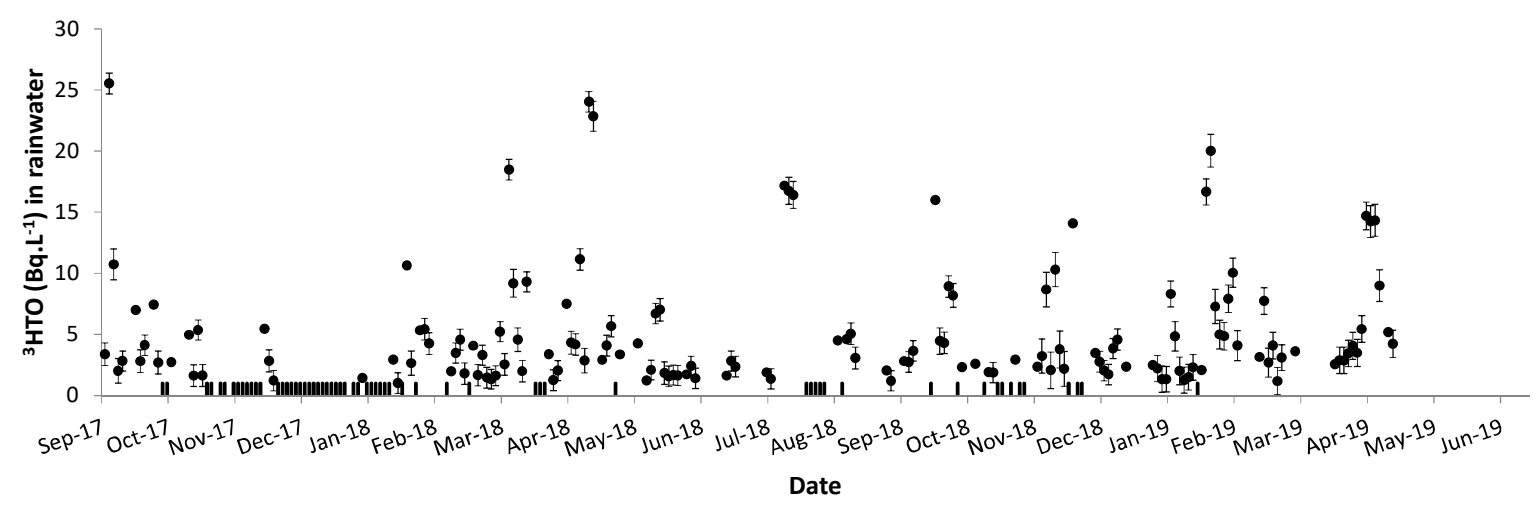


Figure 5: BoxPlots of ${ }^{3} \mathrm{H}\left(\mathrm{Bq} \cdot \mathrm{L}^{-1}\right)$ in rainwater in our site of measurements. Cross represent median, The two ends of the rectangle represents $25-75 \%$ percentile, horizontal bar are average, circle marks min and max measurements (values of average are in italics, values of median are in bold).

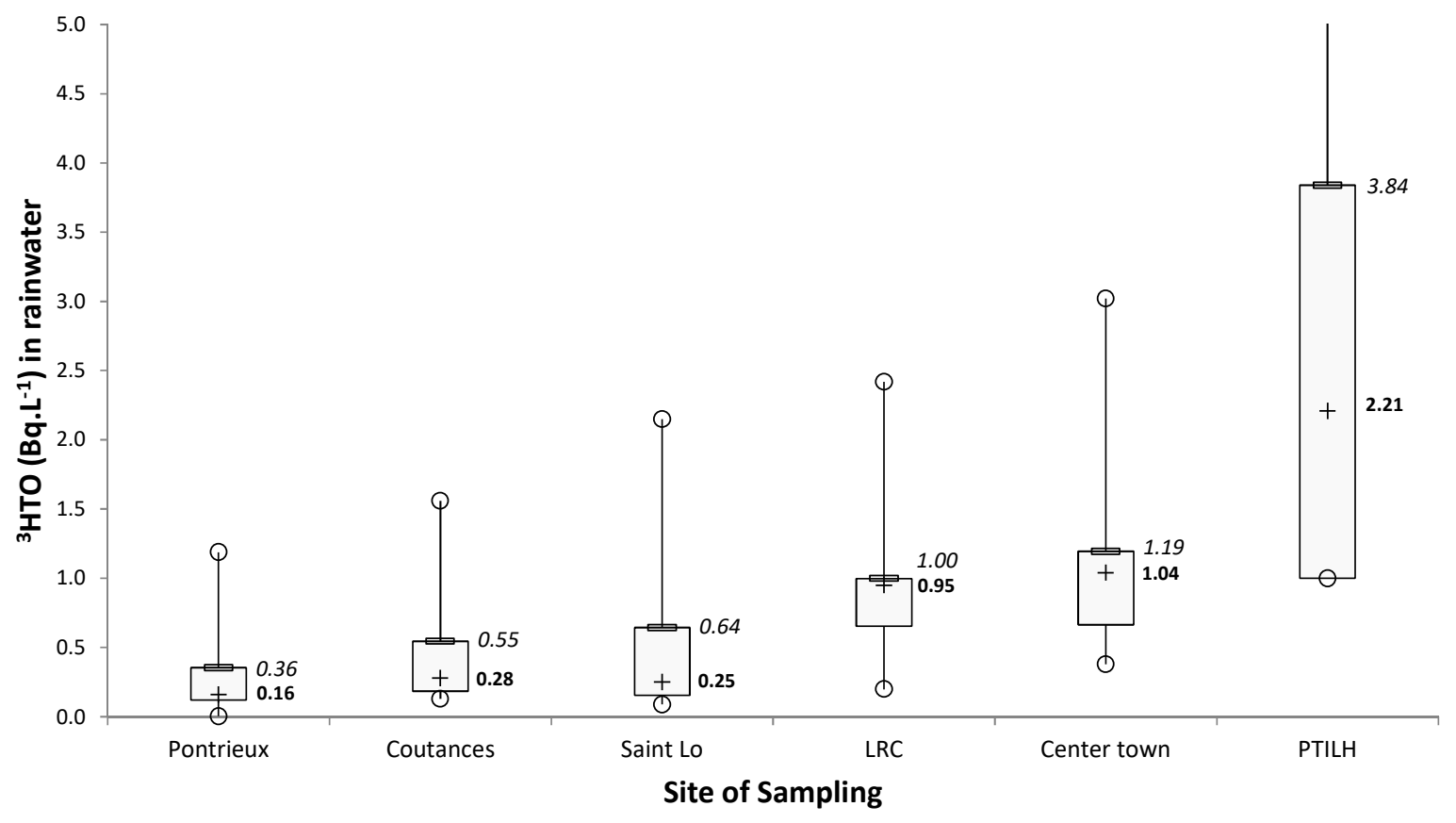


Figure 6 : Normalised ${ }^{3} \mathrm{H}$ in function of rainfall $(\mathrm{mm})$ at Cherbourg-LRC site (a) and PTILH site (b).
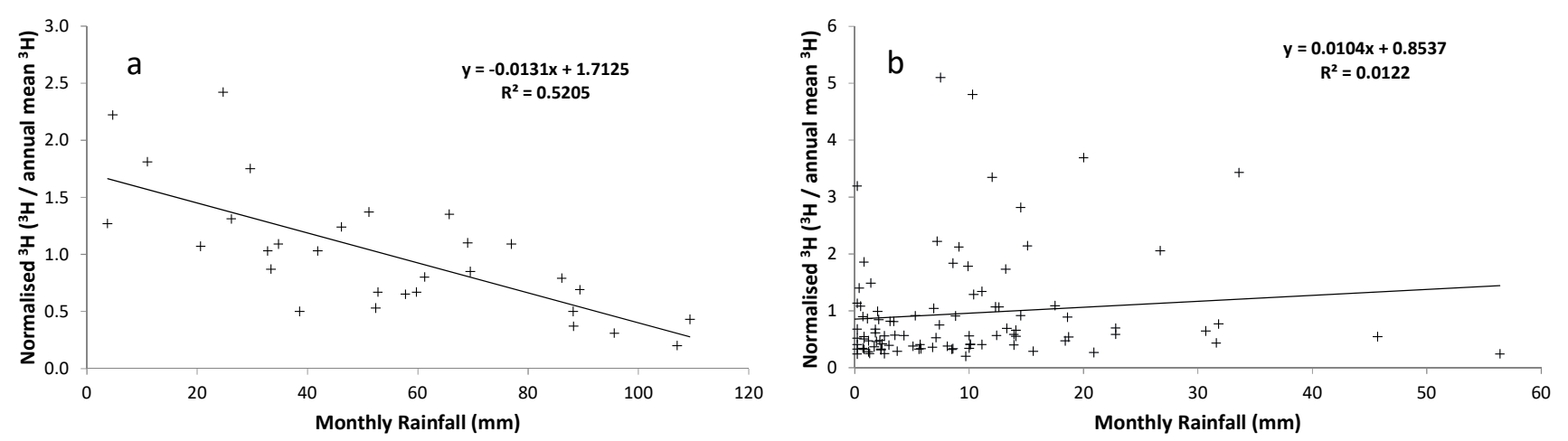
Figure 7 : Evolution of tritium activities in rainwater $\left(\mathrm{Bq} \cdot \mathrm{L}^{-1}\right)$ for IAEA-GNIP stations at Thonon Les Bains (France), Madrid (Spain), Brest (France), Valentia (Ireland), Punta Delgada (Portugal) for 1996-2016 period.

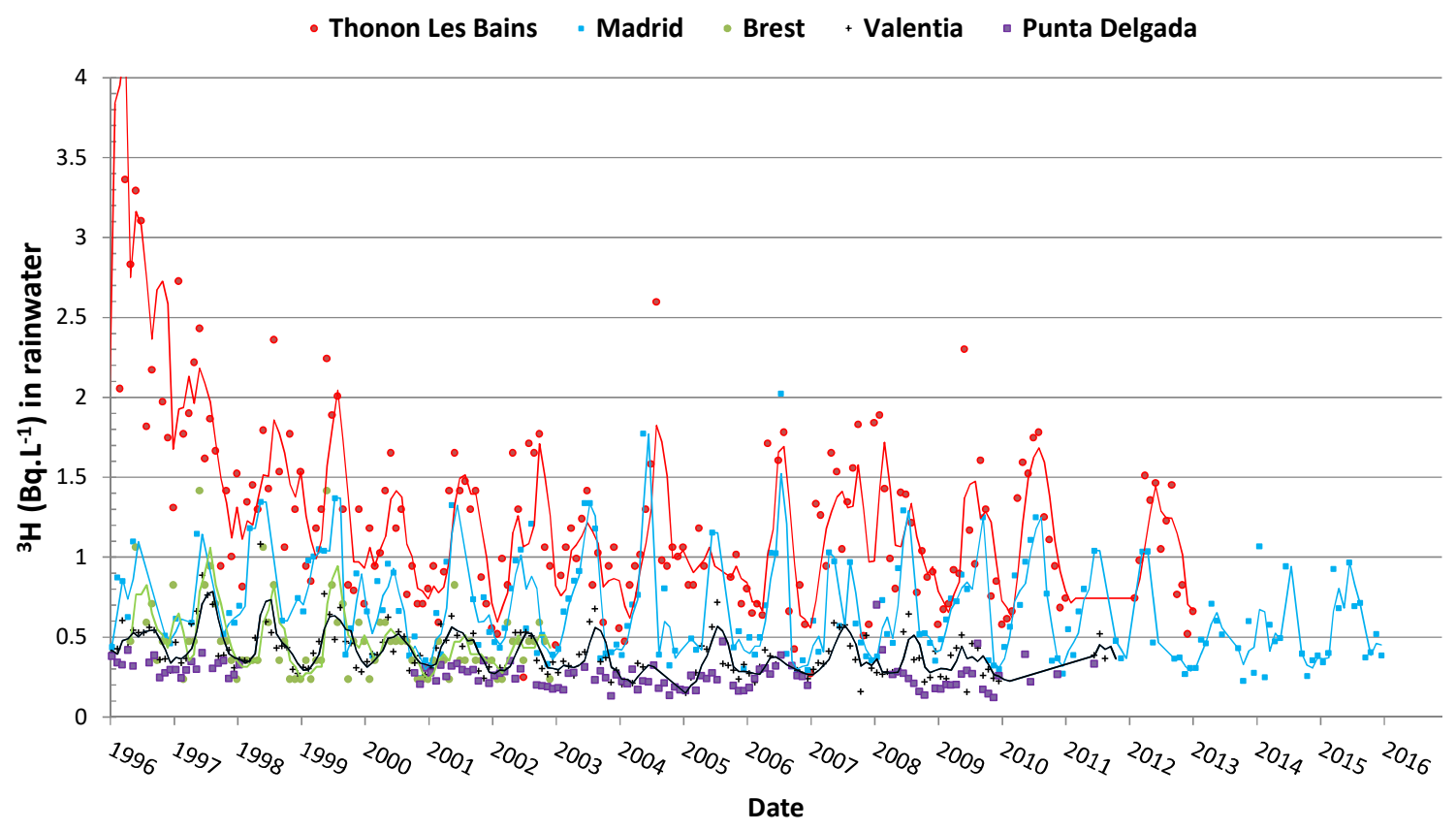


Figure 8: Evolution of tritium activities in rainwater (Bq. $\mathrm{L}^{-1}$ ) for IAEA-GNIP stations at Thonon Les Bains (France), Brest (France), Valentia (Ireland) for 1996-2005 period.

+ Thonon Les Bains + Brest "Valentia

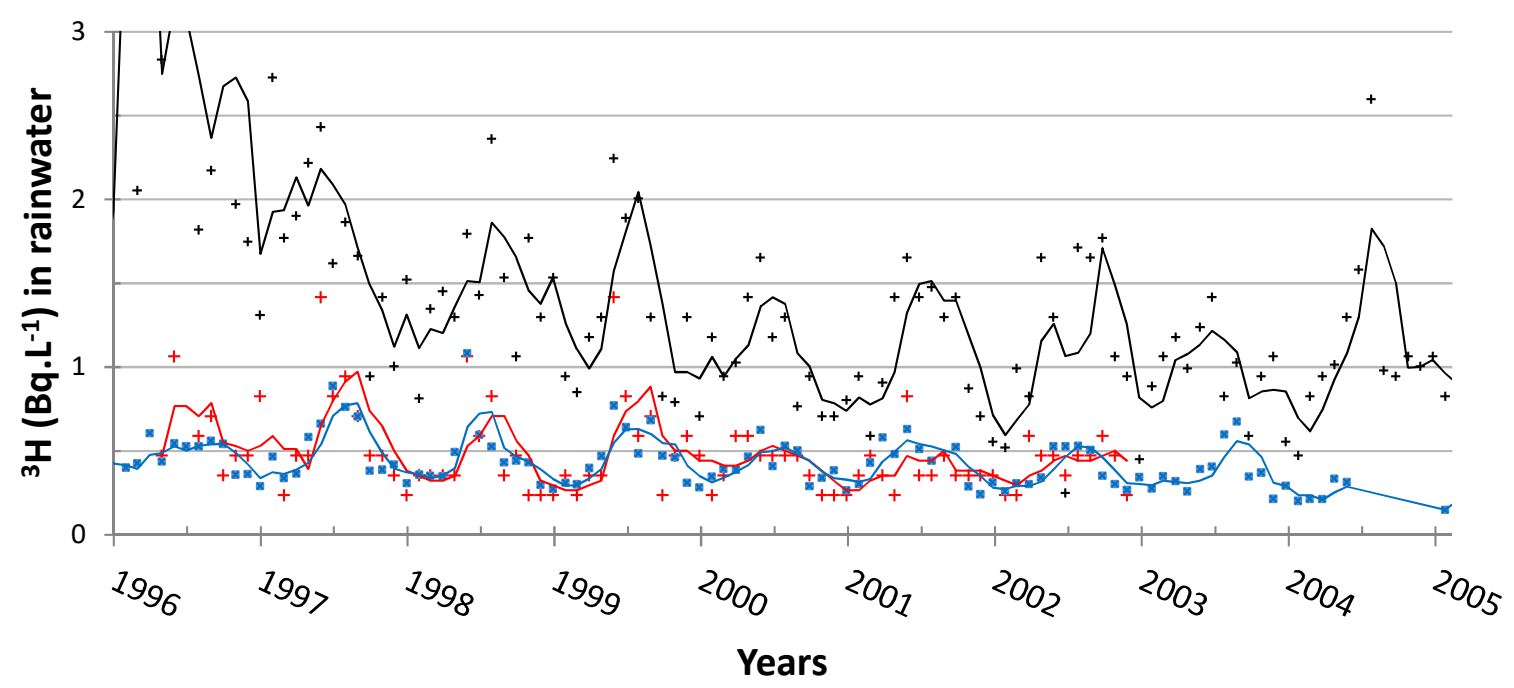


Figure 9 : Simulation by sine function of tritium activities in rainwater $\left(\mathrm{Bq} . \mathrm{L}^{-1}\right)$ for IAEAGNIP stations at Thonon Les Bains and Valentia between 2007 and 2020, with measurements at Valentia (until 2012), and our measurements in this work at Pontrieux (square), Cherbourg -LRC (black circles) and Lusignan (green circles) sites.

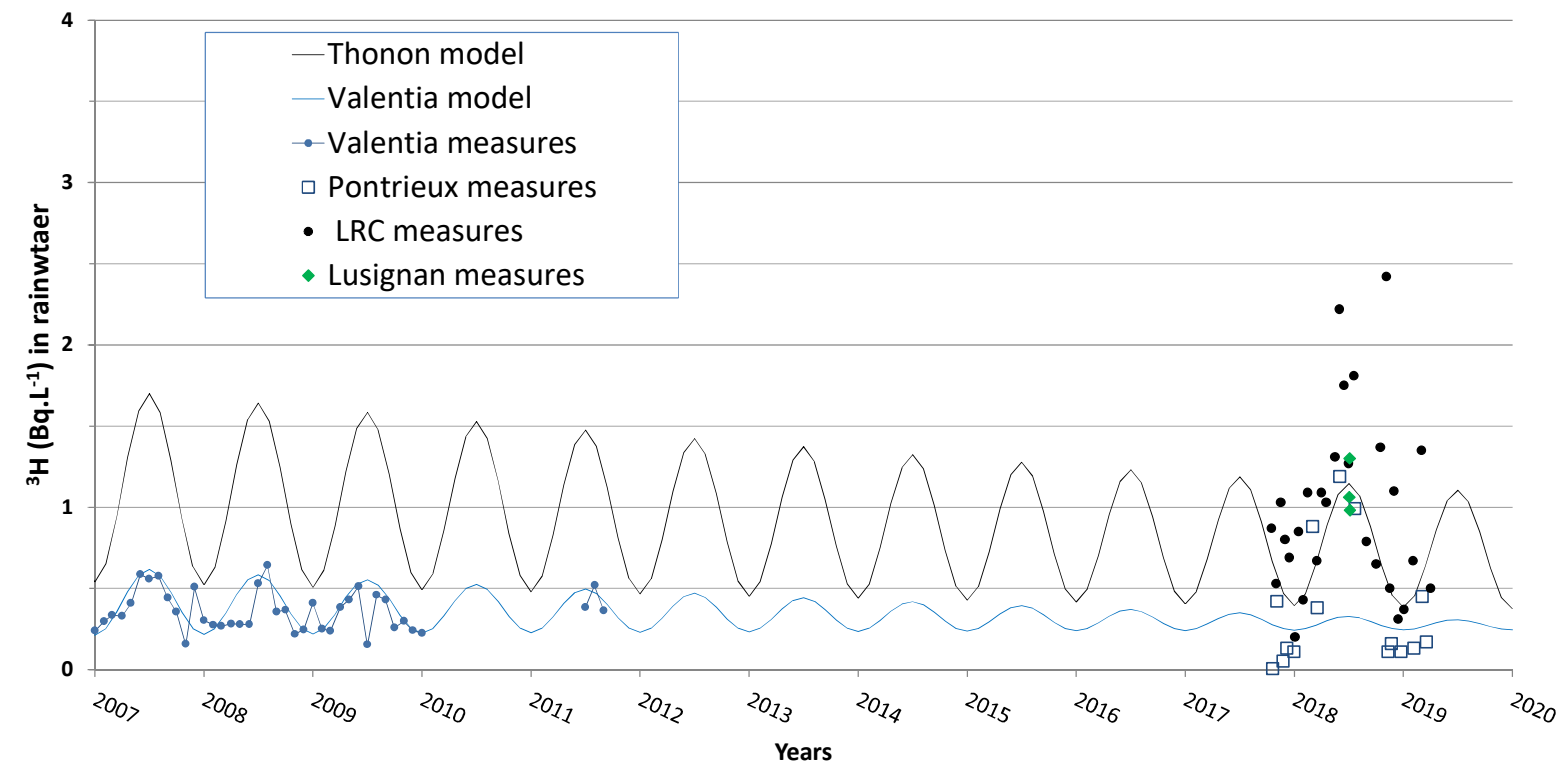


Table 1: Tritium activities in rainwater $\left(\mathrm{Bq} \cdot \mathrm{L}^{-1} \pm 2 \sigma\right)$ at Pontrieux site, and origin of air masses during $72 \mathrm{~h}$ before sampling (values lower than $0.15 \mathrm{~Bq} \cdot \mathrm{L}^{-1}$ are values $<\mathrm{SD}$ and indicate here to calculate average).

\begin{tabular}{|c|c|c|c|c|c|c|}
\hline date start (TU) & date end (TU) & & $3 q$ & & Air mass origin & remarks \\
\hline 19/10/2017 14:30 & 19/10/2017 17:15 & 0.01 & \pm & 0.16 & SSW-Atlantic & $<\mathrm{SD}$ \\
\hline 03/11/2017 17:00 & 04/11/2017 07:00 & 0.42 & \pm & 0.17 & SE-N-Channel & \\
\hline 23/11/2017 15:30 & 24/11/2017 18:15 & 0.05 & \pm & 0.15 & W-Atlantic & $<\mathrm{SD}$ \\
\hline 06/12/2017 17:00 & 07/12/2017 11:00 & 0.13 & \pm & 0.15 & SW-Atlantic & $<\mathrm{SD}$ \\
\hline 28/12/2017 18:00 & 29/12/2017 09:00 & 0.11 & \pm & 0.16 & W-Atlantic & $<\mathrm{SD}$ \\
\hline 01/03/2018 17:00 & 02/03/2018 08:00 & 0.88 & \pm & 0.17 & SE-land & \\
\hline 15/03/2018 17:00 & 17/03/2018 07:00 & 0.38 & \pm & 0.16 & SE-land & \\
\hline $31 / 05 / 2018$ 12:00 & $31 / 05 / 2018$ 16:00 & 1.19 & \pm & 0.16 & S-land & \\
\hline 21/07/2018 06:00 & $21 / 07 / 2018$ 10:00 & 0.99 & \pm & 0.16 & W-S-land & \\
\hline 09/11/2018 17:00 & $10 / 11 / 201810: 00$ & 0.11 & \pm & 0.15 & W-Atlantic & $<\mathrm{SD}$ \\
\hline 21/11/2018 07:30 & $22 / 11 / 2018$ 17:00 & 0.16 & \pm & 0.15 & E-land & \\
\hline $22 / 12 / 201816: 00$ & 23/12/2018 09:00 & 0.11 & \pm & 0.15 & SW-Atlantic & $<\mathrm{SD}$ \\
\hline 05/02/2019 14:00 & 06/02/2019 08:00 & 0.13 & \pm & 0.15 & SW-Atlantic & $<\mathrm{SD}$ \\
\hline 03/03/2019 16:00 & 04/03/2019 09:00 & 0.45 & \pm & 0.16 & NW-Channel & \\
\hline $13 / 03 / 201916: 00$ & 18/03/2019 09:00 & 0.17 & \pm & 0.15 & N-Channel & \\
\hline
\end{tabular}


Table 2: Tritium activities in rainwater $\left(B q . \mathrm{L}^{-1} \pm 2 \sigma\right)$ at Coutances, Saint-Lô and CherbourgCenter town site (values lower than $0.15 \mathrm{~Bq} . \mathrm{L}^{-1}$ are values $<\mathrm{SD}$ and indicate here to calculate average).

\begin{tabular}{|c|c|c|c|c|c|c|}
\hline site & date start (TU) & date end (TU) & \multicolumn{3}{|c|}{${ }^{3} \mathrm{H} \mathrm{Bq} \cdot \mathrm{L}^{-1}$} & remarks \\
\hline \multirow[t]{10}{*}{ Coutances } & 09/10/2018 12:30 & $18 / 10 / 2018$ 13:30 & 1.05 & \pm & 1.05 & \\
\hline & $18 / 10 / 201815: 00$ & 08/11/2018 15:00 & 1.56 & \pm & 0.19 & \\
\hline & 08/11/2018 15:00 & $26 / 11 / 2018$ 11:15 & 0.13 & \pm & 0.16 & $<\mathrm{SD}$ \\
\hline & $26 / 11 / 2018$ 11:15 & 06/12/2018 13:15 & 0.16 & \pm & 0.16 & \\
\hline & $06 / 12 / 2018$ 13:15 & $17 / 12 / 201810: 35$ & 0.28 & \pm & 0.14 & \\
\hline & $17 / 12 / 2018$ 10:35 & 07/01/2019 10:30 & 0.43 & \pm & 0.16 & \\
\hline & 07/01/2019 10:30 & $22 / 01 / 2019$ 13:10 & 0.21 & \pm & 0.16 & \\
\hline & $22 / 01 / 201913: 10$ & 04/02/2019 08:25 & $<1$ & & & \\
\hline & 04/02/2019 08:25 & $25 / 02 / 2019$ 10:00 & $<1$ & & & \\
\hline & $25 / 02 / 201910: 00$ & $25 / 03 / 201906: 00$ & $<1$ & & & \\
\hline \multirow[t]{8}{*}{ Saint-Lô } & $11 / 10 / 201806: 25$ & 19/10/2018 10:50 & 1.36 & \pm & 0.20 & \\
\hline & 19/10/2018 15:00 & 06/11/2018 15:00 & 2.15 & \pm & 0.20 & \\
\hline & 06/11/2018 08:50 & 26/11/2018 07:15 & 0.19 & \pm & 0.16 & \\
\hline & $26 / 11 / 2018$ 07:00 & 10/12/2018 07:00 & 0.09 & \pm & 0.15 & $<\mathrm{SD}$ \\
\hline & 10/12/2018 07:00 & $21 / 12 / 2018$ 11:00 & 0.12 & \pm & 0.15 & $<\mathrm{SD}$ \\
\hline & $21 / 12 / 2018$ 11:00 & 08/01/2019 07:00 & 0.35 & \pm & 0.16 & \\
\hline & 08/01/2019 07:00 & 28/01/2019 09:00 & 0.25 & \pm & 0.16 & \\
\hline & 28/01/2019 09:00 & 04/03/2019 08:00 & $<1$ & & & \\
\hline \multirow[t]{11}{*}{ Cherbourg-Center town } & $25 / 09 / 2018$ 15:00 & 09/10/2018 14:00 & 2.08 & \pm & 0.21 & \\
\hline & 09/10/2018 14:00 & 23/10/2018 13:00 & 1.18 & \pm & 0.19 & \\
\hline & $23 / 10 / 2018$ 15:00 & 06/11/2018 15:00 & 3.02 & \pm & 0.23 & \\
\hline & 06/11/2018 15:00 & 20/11/2018 12:00 & 0.93 & \pm & 0.17 & \\
\hline & 20/11/2018 12:00 & $04 / 12 / 2018$ 15:00 & 0.73 & \pm & 0.16 & \\
\hline & $04 / 12 / 201815: 00$ & $18 / 12 / 201815: 00$ & 0.38 & \pm & 0.15 & \\
\hline & $18 / 12 / 201815: 00$ & 02/01/2019 09:00 & 0.56 & \pm & 0.16 & \\
\hline & 02/01/2019 09:00 & $15 / 01 / 201915: 00$ & 1.04 & \pm & 1.00 & \\
\hline & $15 / 01 / 201815: 00$ & 29/01/2019 15:00 & 0.60 & \pm & 0.17 & \\
\hline & 29/01/2019 15:00 & $13 / 02 / 201908: 30$ & 1.38 & \pm & 0.81 & \\
\hline & $24 / 02 / 2019$ 15:00 & $12 / 03 / 201915: 00$ & 1.24 & \pm & 1.05 & \\
\hline
\end{tabular}


Figure 1: (a) Location of the global network of isotopes precipitation (GNIP) stations (IAEA/WMO 2019) used in this work (yellow dots) and (b) location of local sampling site of our study (white and red dots). Positions of nuclear facilities were reported on (b).

Figure 2: (a) Pluviometer Eigenbrodt used at Cherbourg-LRC site, (b) Pluviometer used on others sites.

Figure 3: Evolution of tritium activities in rainwater (Bq. $\left.\mathrm{L}^{-1}\right)$ at Cherbourg-LRC site (biMonthly measurements), at Pontrieux and Cherbourg Center Town sites (intermittent measurements). The dotted line represent the decision thresholds for our measurements (below its 'uncensored' values).

Figure 4: Evolution of tritium activities in rainwater $\left(\mathrm{Bq} \cdot \mathrm{L}^{-1}\right)$ at Omonville La Petite PTILH site (the black bar represent activities $<1$ Bq. $\mathrm{L}^{-1}$ ).

Figure 5: BoxPlots of ${ }^{3} \mathrm{H}\left(\mathrm{Bq} . \mathrm{L}^{-1}\right)$ in rainwater in our site of measurements. Cross represent median, The two ends of the rectangle represents $25-75 \%$ percentile, horizontal bar are average, circle marks min and max measurements (values of average are in italics, values of median are in bold).

Figure 6: Normalised ${ }^{3} \mathrm{H}$ in function of rainfall (mm) at Cherbourg-LRC site (a) and PTILH site (b).

Figure 7: Evolution of tritium activities in rainwater (Bq.L $\left.{ }^{-1}\right)$ for IAEA-GNIP stations at Thonon Les Bains (France), Madrid (Spain), Brest (France), Valentia (Ireland), Punta Delgada (Portugal) for 1996-2016 period.

Figure 8: Evolution of tritium activities in rainwater (Bq. $\mathrm{L}^{-1}$ ) for IAEA-GNIP stations at Thonon Les Bains (France), Brest (France), Valentia (Ireland) for 1996-2005 period.

Figure 9: Simulation by sine function of tritium activities in rainwater (Bq. $\left.\mathrm{L}^{-1}\right)$ for IAEAGNIP stations at Thonon Les Bains and Valentia between 2007 and 2020, with measurements at Valentia (until 2012), and our measurements in this work at Pontrieux (square), Cherbourg -LRC (black circles) and Lusignan (green circles) sites.

Table 1: Tritium activities in rainwater $\left(\mathrm{Bq} \cdot \mathrm{L}^{-1} \pm 2 \sigma\right)$ at Pontrieux site, and origin of air masses during $72 \mathrm{~h}$ before sampling (values lower than $0.15 \mathrm{~Bq} \cdot \mathrm{L}^{-1}$ are values $<\mathrm{SD}$ and indicate here to calculate average).

Table 2: Tritium activities in rainwater $\left(B q . L^{-1} \pm 2 \sigma\right)$ at Coutances, Saint-Lô and CherbourgCenter town site (values lower than $0.15 \mathrm{~Bq} \cdot \mathrm{L}^{-1}$ are values $<\mathrm{SD}$ and indicate here to calculate average). 